Editorial

\title{
Why the Development of Internal Combustion Engines Is Still Necessary to Fight against Global Climate Change from the Perspective of Transportation
}

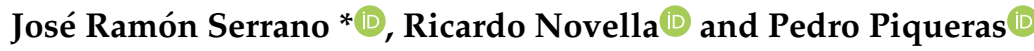 \\ CMT—Motores Térmicos, Universitat Politècnica de València, 46022 València, Spain; rinoro@mot.upv.es (R.N.); \\ pedpicab@mot.upv.es (P.P.) \\ * Correspondence: jrserran@mot.upv.es
}

Received: 26 September 2019; Accepted: 4 October 2019; Published: 29 October 2019

check for updates

Internal combustion engines (ICE) are the main propulsion systems in road transport. In mid-2017, Serrano [1] referred to the impossibility of replacing them as the power plant in most vehicles. Nowadays, this statement is true even when considering the best growth scenario for all-electric and hybrid vehicles. The arguments supporting this position consider the growing demand for transport, the strong development of cleaner and more efficient ICEs [2,3], the availability of fossil fuels, and the high energy density of said conventional fuels. Overall, there seems to be strong arguments to support the medium-long-term viability of ICEs as the predominant power plant for road transport applications. However, the situation has changed dramatically in the last few years. The media and other market players are claiming the death of ICEs in the mid-term [4]. Politicians from several G7 countries, such as France, Spain, and the United Kingdom, have announced the prohibition of ICEs in their markets [5], in some cases, as early as 2040. Large cities, such London, Paris, Madrid, and Berlin, are also considering severe limits to ICE-powered vehicles. What is the analysis that can be made from this new situation?

\section{What Is the Problem with ICE (Internal Combustion Engines)?}

The media's arguments against ICEs range from the need to reduce $\mathrm{CO}_{2}$ emissions (global warming) to the need to improve the air quality in cities (NOx and particulate matter emissions).

Much of this debate about the future of ICEs has arisen from the Dieselgate scandal [6,7]. A horrible wrong decision from a management and engineering point of view at a specific time and place has generated a worldwide butterfly effect in the automotive industry. However, making the problem a virtue, Dieselgate has forced new regulations to obtain much more efficient and cleaner ICEs [8-11].

As commonly takes place, old and lax pollutant regulations have now resulted in a pendular effect toward radically contrary positions, delighting the media and generating excessive political reactions without a clear scientific basis. All this is reflected in the look to publish a sufficiently popular or good news novelty. We could define the situation as energy populism. Although new regulations that force ICE technology to be more environmentally friendly must always be welcome, prohibitions motivated by a poor diagnosis of the situation will not help at all, neither to improve air quality nor to mitigate global warming.

\section{What Is the Problem with Electric Vehicles?}

What should be the alternative to the current ICE in the mid-to-long term? Combining the pendulum effect of public opinion with the excellent marketing of new actors in the passenger car sector, a confusion cocktail is served for the media. After all, one might ask if the use of the conventional propulsive systems over 120 years was the right path. How can such an old concept be innovative? 
How can the ICE be great and technologically advanced at burning fossil fuels? An easy but wrong conclusion comes without the need of reflection: Let us welcome "new electric motors and batteries" in zero-emission cars!

The bad news is that energy is neither created nor destroyed, only transformed. Electric motors and batteries are not new, nor are they clean and, in general, are not free from problems. One can directly identify two relevant problems.

The first problem is that vehicle propulsion involves energy transformations and the electric motor does not use a primary energy source but an energy vector. Although public opinion has a clear idea of how some processes like friction can negatively affect transport applications, the understanding of the impact of the second law of thermodynamics is limited. The problem is that electricity must be produced, most usually from non-renewable energy sources, which equals around $60 \%$ in energy losses, and then transported, which adds $20 \%$ of additional losses. Unfortunately, renewable sources are barely $10 \%$ of the global energy mix, as observed in Figure 1 [12] without a medium-term forecast of significant increase.

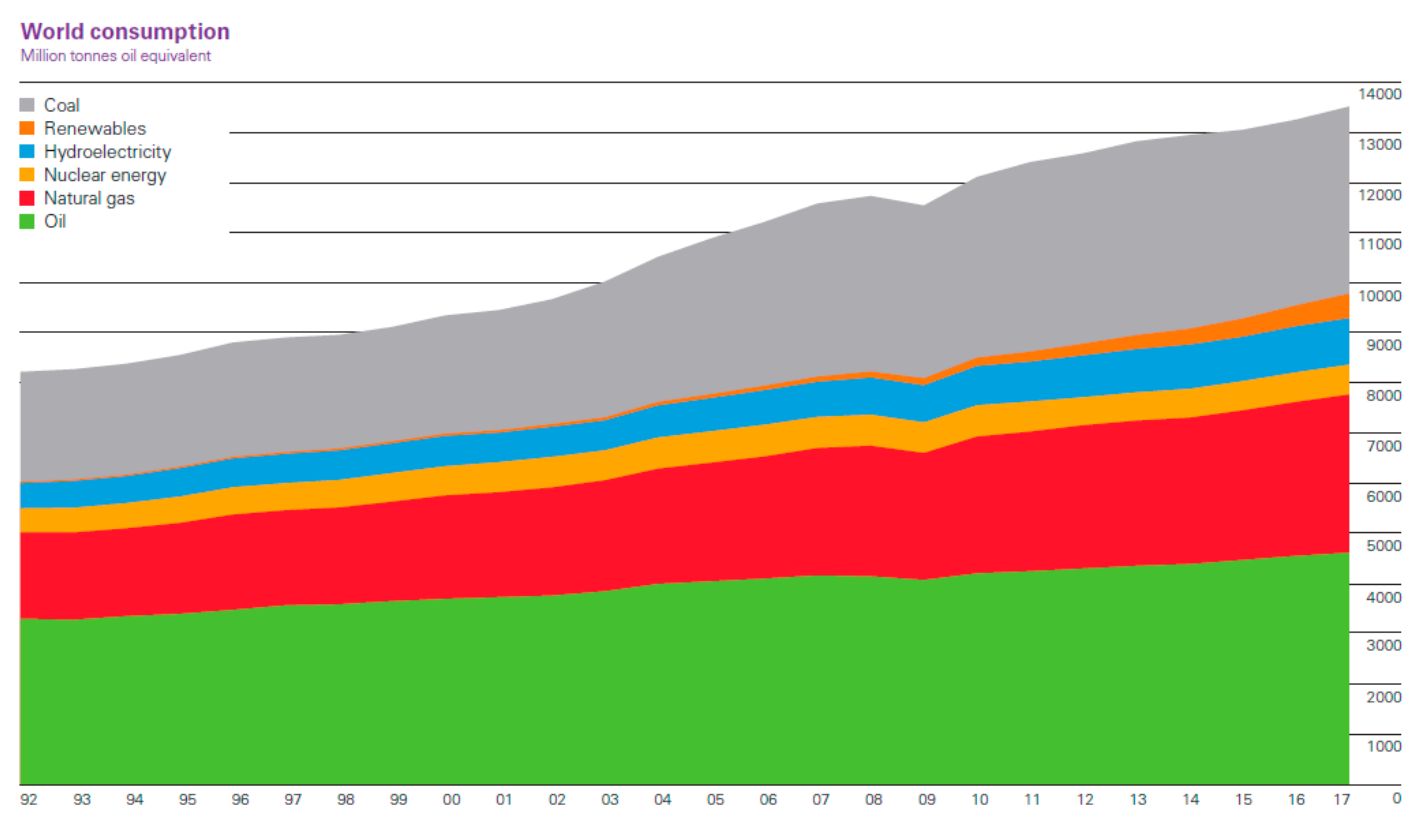

Figure 1. Evolution of world energy consumption by origin during the last 25 years [12].

In some countries like the USA, China, Russia, Poland, South Korea, or Germany, fossil fuels, including a good percentage of coal, remain the largest source of energy as a raw material for electricity production. In a first approach, the only G8 country with real alternatives to $\mathrm{CO}_{2}$-emitting technologies is France due to its continued commitment with nuclear energy. Therefore, with the current energy mix and with an analysis of the complete life cycle, the so-called analysis from the cradle to the grave, the alternative to electric motors will not eliminate global $\mathrm{CO}_{2}$ emissions.

On this concern, Figure 2 [13] which takes the data from the cradle to the grave analysis elaborated by the JEC-Joint Research Centre-EUCAR-CONCAWE collaboration [13] effectively shows how with the European electricity production mix the shift to battery electric vehicles (BEVs) would reduce but not remove $\mathrm{CO}_{2}$ emissions. The reduction of the EU electricity mix is estimated as $40 \mathrm{gCO}_{2} / \mathrm{km}$ (from 210 to $170 \mathrm{gCO}_{2} / \mathrm{km}$ ) in a total shift from ICEs to BEVs. However, the European Union reaches $35 \%$ of the mix between renewable and hydraulic energy sources [12], while worldwide, it is just $10 \%$ (Figure 1). If one thinks that $\mathrm{CO}_{2}$ emission is a global problem, energy policies on this regard cannot be acceptable being regional. 


\section{TRANSPORT CO2 EMISSIONS IN THE EU}

\section{Range of life-cycle $\mathrm{CO}$ emissions for different vehicle and fuel types (2014)}

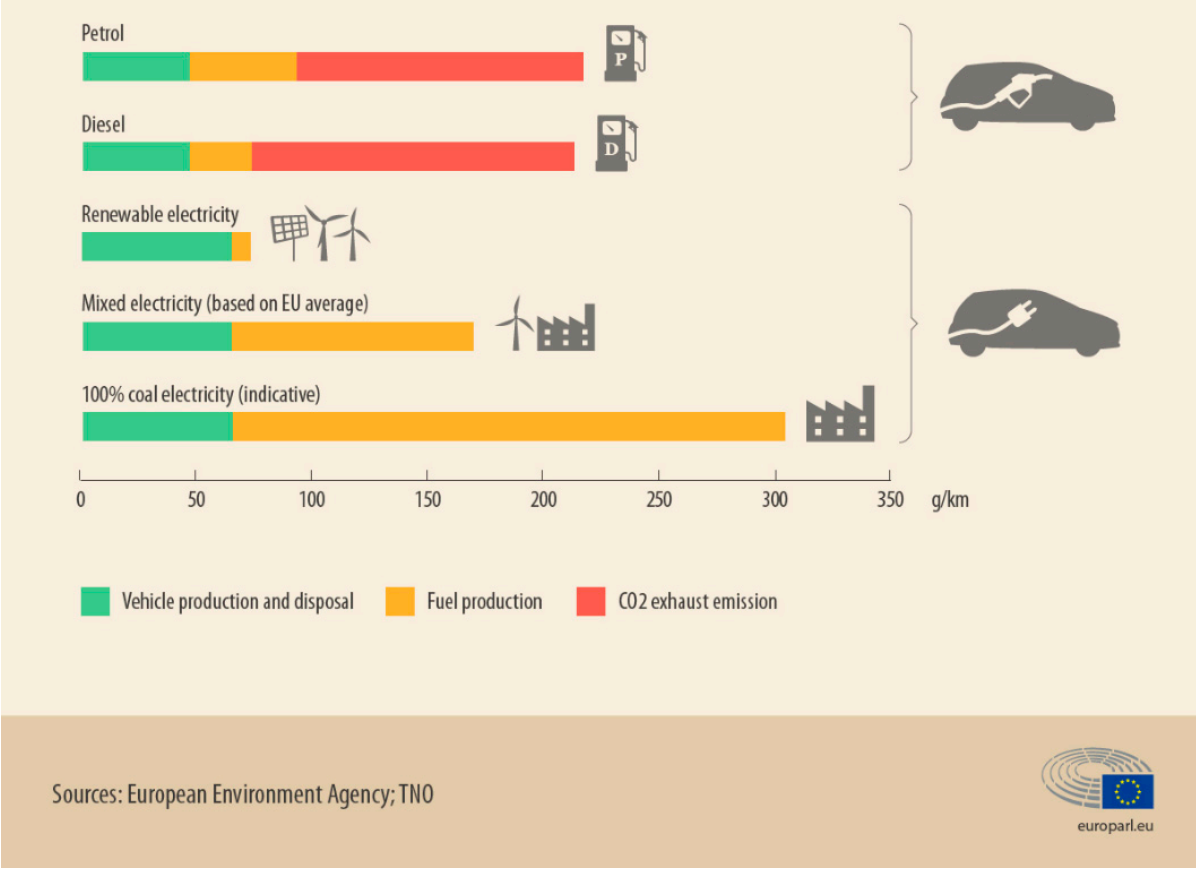

Figure 2. Life-cycle $\mathrm{CO}_{2}$ emissions as a function of the energy source [13] with data from [14].

More recently, in April 2019, the international media echoed a recent study performed by the German IFO (Institute Center for Economic Studies, CESifo GmbH) conducted by Sinn et al. [15], who calculated that a Tesla Class 3 emits from 156 to $180 \mathrm{gCO}_{2} / \mathrm{km}$ during its lifetime with the German energy mix. This result in $\mathrm{CO}_{2}$ emission ranges from $11 \%$ to $28 \%$ more than the modern Diesel E6d Temp engines. In addition, a life cycle analysis of the full electrification of road transport shows that the gaseous emissions would only be relocated from cities to the surroundings of large thermal power plants and manufacturing centers, as pointed out by Messagie [16]. Unfortunately, global warming cannot be relocated and atmospheric phenomena do not know the boundaries, as acid rain and clouds of particulate material (PM 2.5) have repeatedly demonstrated, as shown in Figure 3 [17]. In summary, for the combination of a massive electrification of road transport and the current global energy mix, the maximum benefit is a relocation of the emitted $\mathrm{CO}_{2}$. As no substantial changes are anticipated in the current electric mix until 2030, the electrification of transport as a clear solution to the problem of climate change should be postponed [17]. 


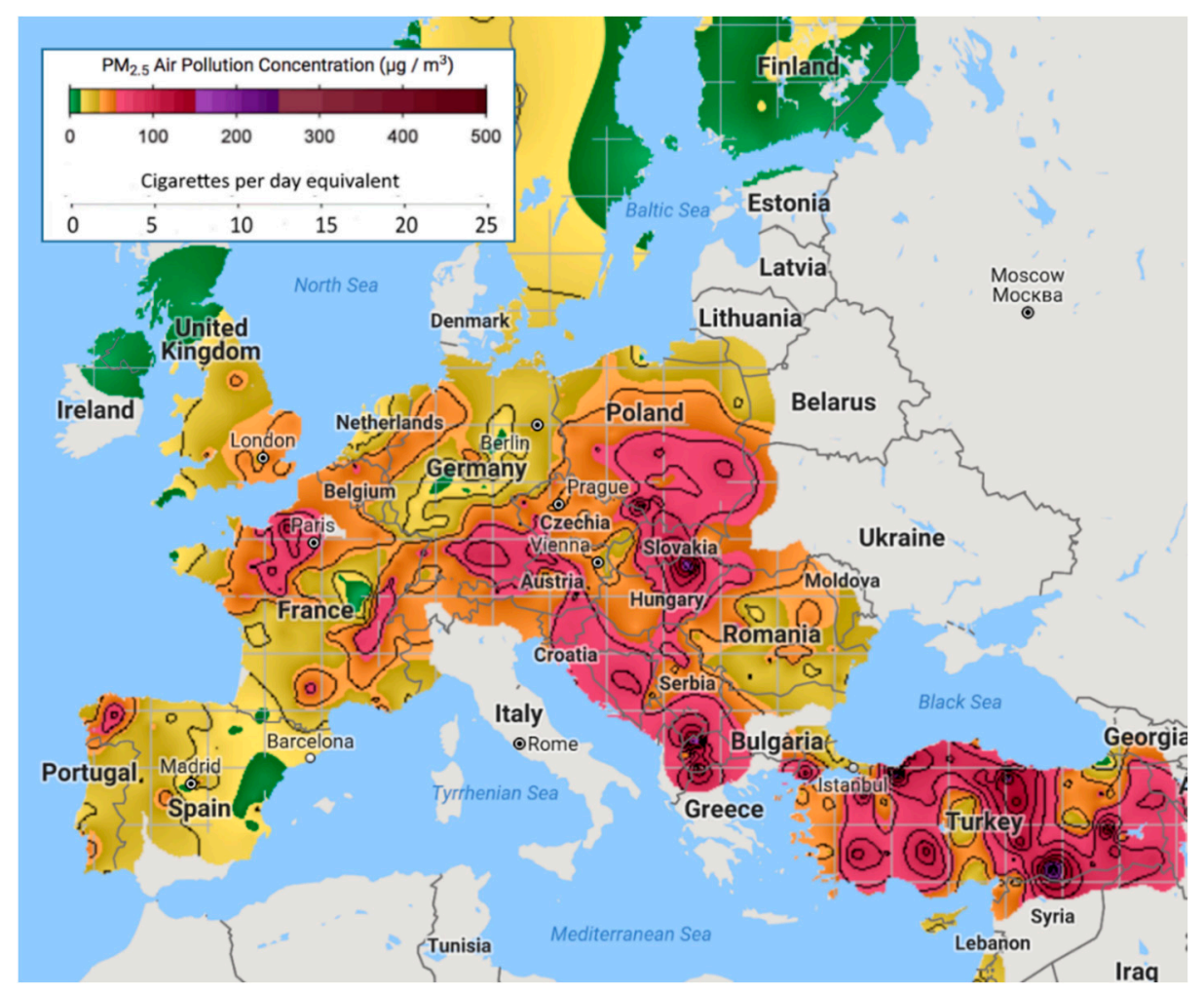

Figure 3. European PM2.5 levels. From [17].

The second problem with electric vehicles comes from the need of electricity storage. In a simple basic way, electricity must be generated as it is consumed. Of course, one can resort to batteries as the electricity storage solution although not in a significant amount for road transport applications. Like the ICE, batteries are an old well-known concept. In addition, batteries also involve harmful chemical compounds. Despite progressive improvements, batteries are a totally immature technology in the range of power and energy required for most road transport applications, where there is no competitor against successfully flexible liquid fuels [18]. There are four challenges that the development of batteries must deal with:

- $\quad$ The charging time of the battery is unacceptably long for many users [19].

- The energy density is unacceptably low with real autonomies below $250 \mathrm{~km}$ in compact vehicles [20] and around $300 \mathrm{~km}$ in sport urban vehicles (SUVs) [21].

- The lifetime of the batteries is limited and less than the vehicle life. Several studies [22,23] show this fact and discuss the risks and costs associated with their recycling or disposal in a proper way.

- The supply of raw materials for manufacturing such as nickel, lithium, cobalt, copper, and manganese among others is an emergent obstacle as they are reaching high prices quickly and gaining in importance on geopolitical strategies. According to Sarah Maryssael, global manager of metal supplies for Tesla [24], the main problem is currently the supply of cobalt, which is necessary for the anode of lithium-ion batteries; a Tesla Model X needs $7 \mathrm{~kg}$ per vehicle and a Tesla Model 3 about $4.5 \mathrm{~kg}$ [25]. This mineral is extracted mainly from the Democratic Republic of Congo, where human rights are violated through child labor and mines stand out by their poor safety conditions, among others [26]. Then, cobalt reaches the international markets and its origin is diluted due to the low traceability of the production chain. Finally, it is fundamentally processed in China, what exemplifies the potential of this technology for further economic stress and uncertainties. What would be the cost of these materials refined in western countries with EU security, environmental, and health standards? It would probably be exorbitant. 


\section{What Can the New Generation of ICE Provide?}

Limitations to greenhouse gases $\left(\mathrm{CO}_{2}\right)$, gaseous pollutants, and noise emissions will be increasingly severe, forcing the automotive industry to invest in more innovative technologies for their reduction [10,27-30]. Real driving emissions tests are being adopted in the major global economic zones as this strategy expands the ICE operational range in which the pollutant emissions must be kept below the approval limits [31-33]. A revolution is approaching with respect to traditional gasoline and diesel engines making the boundaries between them disappear as deeper knowledge and greater control of the combustion process is acquired [34]. Advanced injection systems [35,36], turbochargers [37,38], organic Rankine cycles (ORC) [39], hybridization [40,41], multifuel solutions [42-44], or advanced combustion concepts are becoming a part of the ICE context. All these strategies are dedicated to extract every Joule of energy from the fuel. The research on aftertreatment systems based on monolithic reactors offers interesting possibilities to effectively clean the exhaust gases to incredible limits [45]. Nowadays, the automotive industry does not find anything too innovative or risky to meet the expected, medium-term demand for cleaner and more efficient ICE. Finally, fossil fuels are cheap and available. Oil depletion is no longer a topic of discussion as fracking technology has offered a new paradigm, leading the USA to the largest producer of fossil fuels in the world [12].

\section{What Is Improving the Expectations in the New-Generation ICE?}

ICE emits particulate matter, gaseous pollutants, and $\mathrm{CO}_{2}$ locally. This is accepted as it is accepted that electric cars do not. Assuming both particulars are great arguments for the replacement of ICEs, what would happen if the situation were somehow the opposite? In a life cycle analysis, neither the production of the batteries nor the production of electricity is free of $\mathrm{CO}_{2}$ emissions and pollutants [15]. The generation of electricity causes $\mathrm{CO}_{2}$ emissions much greater than the synthesis of liquid fossil fuels, as shown in Figure 2, as it is an energy vector more difficult to obtain and transport. It can be similarly stated that the manufacturing of ICE generates $\mathrm{CO}_{2}$ emissions, although less than in the case of batteries and electric motors [46,47], as also shown in Figure 2.

What can ICE do to increase air quality? We can affirm that modern Euro 6d Temp Diesel engines can clean the air from particulate and smog in heavily polluted areas, such as the situations referred in China [48]. The particulate filters of modern internal combustion engines reduce the level of PM10 below the mean atmospheric value, as shown in Figure 4 [49]. If one combines data in Figures 3 and 4, the advantages of ICE with particulate filters in countries such as Poland, where almost $50 \%$ of their energy mix depends exclusively on coal [12], are evident.

The technology is available, and the research is driven to allow the next generation of ICEs to act as air pollutant cleaners in large cities, whose source of pollution is not only road traffic of old ICEs. This is something that electric motors with batteries cannot do. The new Diesel Euro 6d Temp is emitting $80 \%$ less NOx than stipulated by the standard. This means that they are cleaning the air of emissions coming from other sources [50]. Effective energy policies are needed to renew transport fleets around the world, as justified in [51] for the Europe case, and promote in all countries the same emission standards for ICE as in the United States, Japan, or Europe. The discussion should not focus on the type of technology but on having in the streets the most modern versions of it.

Another important fact concerning ICEs is that the contribution of transport to global emissions of GWPs (Global Warming Potential) has historically remained at 11\%. As shown in Figure 5 elaborated from the United Nations Food and Agriculture Organization (FAO) data [52], industry, agriculture, resource extraction, waste processing, and residential and commercial consumption do the rest. Therefore, a worldwide massive change to electric vehicles would mean a potential worldwide reduction of $11 \%$ of the equivalent tons of $\mathrm{CO}_{2}$ that is emitted under the assumption of using fully $\mathrm{CO}_{2}$-free energy sources for the BEVs batteries charge. 

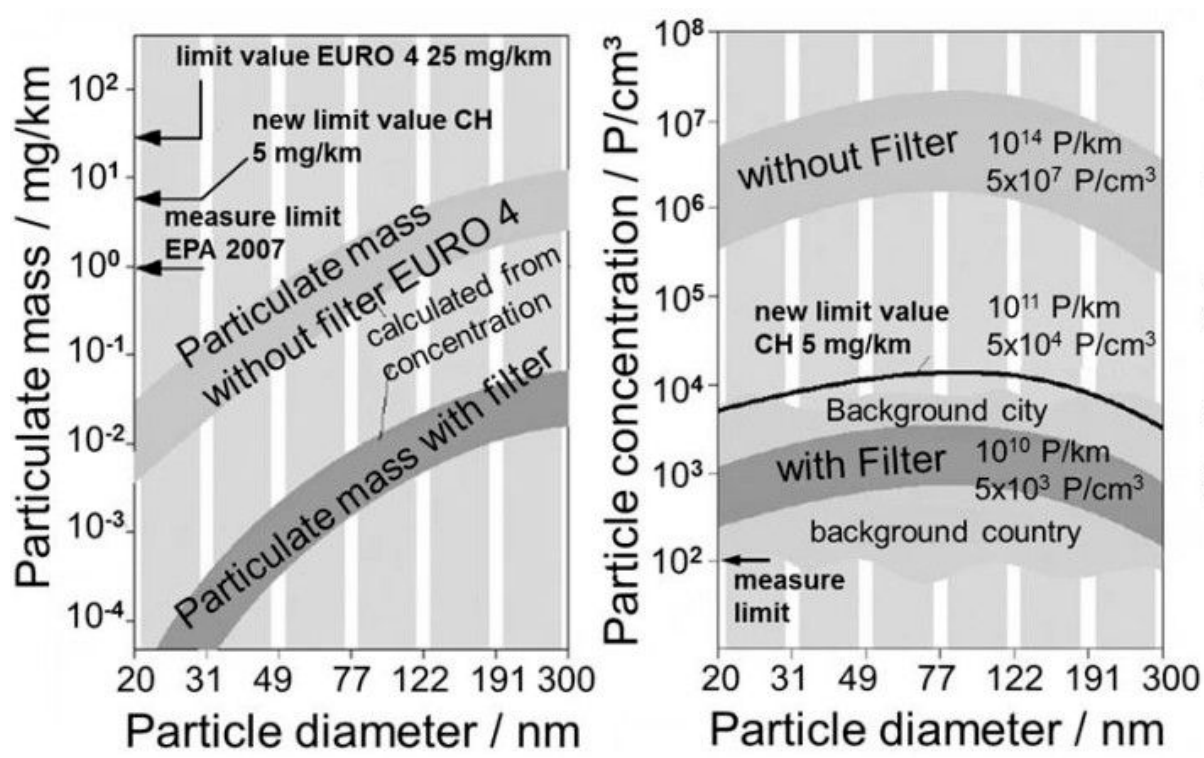

Figure 4. Diesel internal combustion engine (ICE) equipped with particulate filters as air cleaners in urban areas [49].

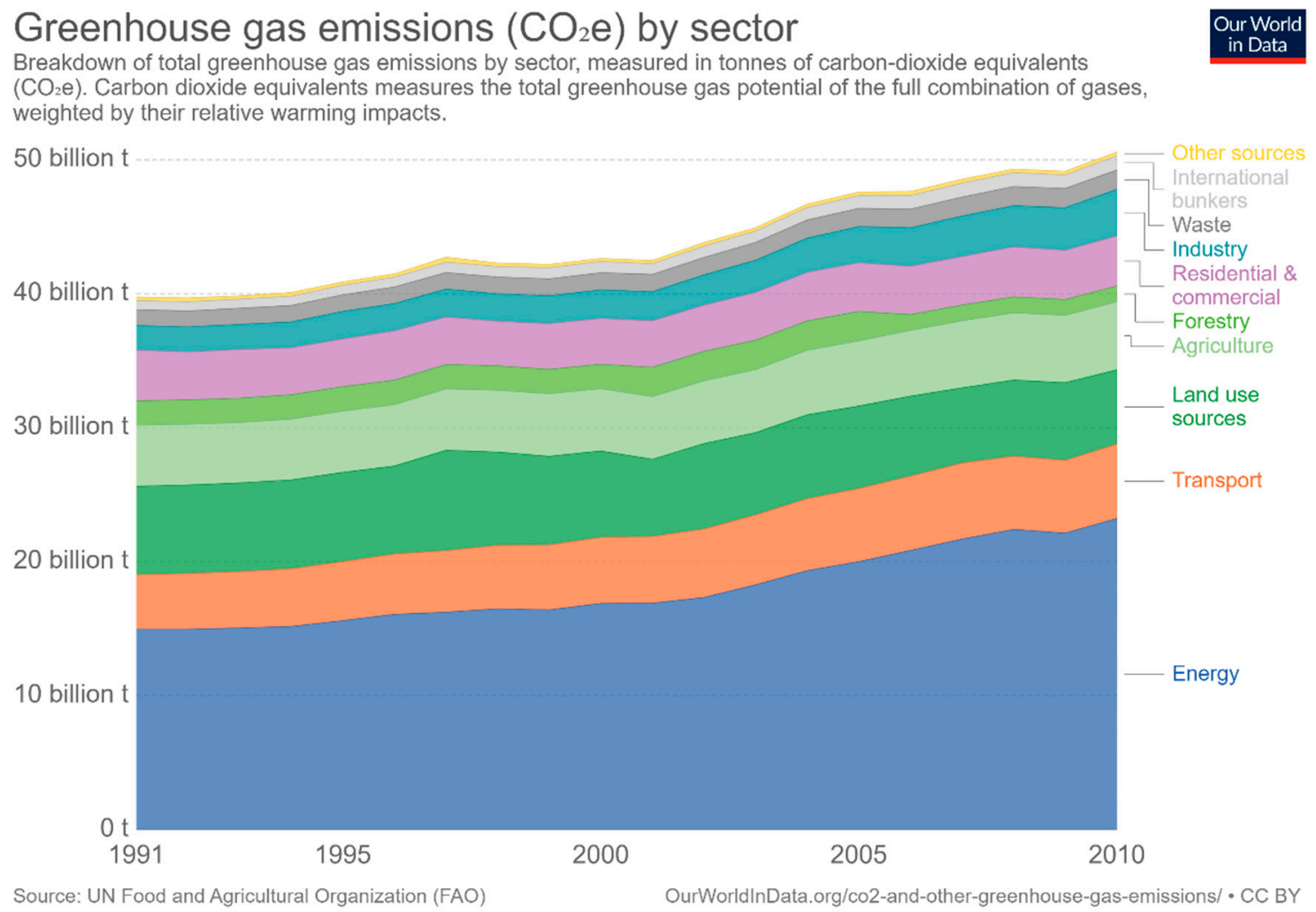

Figure 5. Breakdown of total greenhouse gas emissions by sector, measured in tons of carbon-dioxide equivalents [52].

However, only $10 \%$ of world energy consumption is free of $\mathrm{CO}_{2}$ [12], which means that in best of cases, the reduction would be $10 \%$ of $11 \%$. Even the previously calculated $1.1 \%$ is not fully reachable in a life cycle analysis, as shown in Figure 2. In the very long term, it can be argued that electric cars will substantially lower their $\mathrm{CO}_{2}$ emissions if electricity comes exclusively from renewable or nuclear sources. As can be seen in Figure 6, despite the large dispersion of data in the sources [13,15,16,18], 
this scenario is far from being fulfilled today in most of the European Union countries. Considering countries like Germany or Spain with around 35\% of renewable sources in the mix, the average equivalent $\mathrm{CO}_{2}$ emissions are slightly better than 2019 Diesels E6d Temp. If we make an extrapolation to the future, in the central scenario, we would need to increase the mix of renewables by over $60 \%$ to have the same competitive advantage over combustion technologies based on compression ignition (CI) in $\mathrm{CO}_{2}$ emissions $[15,18]$. Even if we reach $100 \%$ renewable, electric vehicles would never have zero $\mathrm{CO}_{2}$-equivalent emissions if one considers the life cycle and not only local use.

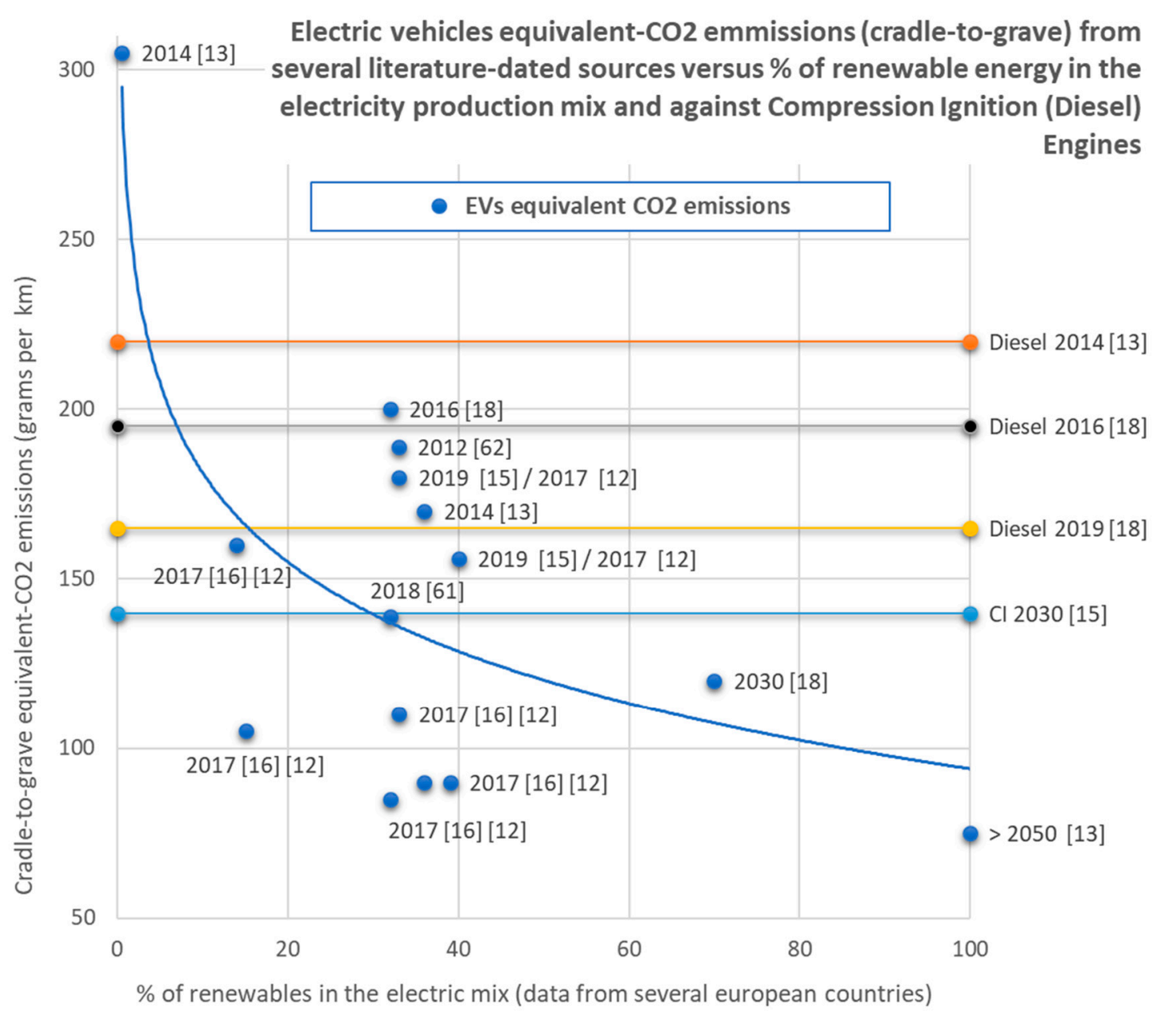

Figure 6. Equivalent life-cycle $\mathrm{CO}_{2}$ emissions of electric vehicles as a function of the percentage of renewables in the electric energy production mix. Comparison with compression ignition (CI) or diesel engines. Elaborated from the references of this publication.

If one imagines that $60 \%$ of renewable sources in the energy mix were the medium-long term standard, could the ICE do so well? The answer is yes and even better if we use synthetic fuels from the capture and use of atmospheric $\mathrm{CO}_{2}$ (CCU) [53]. There are already several R\&D projects in Switzerland, Germany, and Canada focused on CCU. These are systems capable of transforming $\mathrm{CO}_{2}$ taken directly from the air into liquid fuels called 'PtX fuels' (e-fuels, including e-Diesel). This is done by hydrogenation of $\mathrm{CO}_{2}$ using $\mathrm{H} 2$ produced by electrolysis from renewable sources [54]. There are also projects to pump the captured $\mathrm{CO}_{2}$ from the power plants to the oil wells and subsequently convert it into neutral oil from the $\mathrm{CO}_{2}$ point of view. Other studies approach $\mathrm{CO}_{2}$-capturing vehicles, both its own $\mathrm{CO}_{2}$ emission and atmospheric $\mathrm{CO}_{2}$, to generate $\mathrm{CO}_{2}$ neutral fuel on board [55]. That way, the self-CCU could even contribute to a reduction in atmospheric $\mathrm{CO}_{2}$. If the fuels used in these $\mathrm{CO}_{2}$ capture cars were mostly biofuels [56], as is the case in Brazil, this would represent an efficient way 
to remove $\mathrm{CO}_{2}$ from the atmosphere. However, the development of this technology is subject to the efficient recovery of exhaust gas energy from ICEs [57]. In conclusion, if a paradigm change is required, then vehicles acting as $\mathrm{CO}_{2}$ captors to create a $\mathrm{CO}_{2}$ circular economy may arise as the most efficient solution. They would eliminate the other $90 \%$ of $\mathrm{CO}_{2}$ that transport is not producing [57]. This is an opportunity that BEVs cannot offer.

Public funding and government efforts should promote research to reduce polluting emissions, rather than to choose winners for an uncertain future. Direct subsidies to any industry or technology and the banning of others, without enough scientifically proved arguments, is the type of risk exercise that has never been successful. It seems that the European authorities have finally begun to listen to scientists and engineers, which are claiming for the cleaning potential of cities air contamination by the last-generation ICEs depollution systems [58,59], and that explain the facts of the situation [60-62]. The German Bundestag in May 2019 proposed that Euro 6d Temp diesel engines cannot be banned in German cities, not even the Euro 4 and Euro 5 when they emit less than $270 \mathrm{mgNOx} / \mathrm{km}$ (retrofit) that is pending being certified by the German Supreme Court [63]. In France, it is being studied to give the maximum environmental rating to Euro $6 \mathrm{~d}$ Temp Diesel engines after finding that they are as much or cleaner than gasoline engines [64]. In general, promoting research activities of any technology, regardless of the field of research, has always provided great benefits for future generations, and has usually been the cheapest path for the society to progress.

Conflicts of Interest: The authors declare no conflict of interest.

\section{References}

1. Serrano, J.R. Imagining the Future of the Internal Combustion Engine for Ground Transport in the Current Context. Appl. Sci. 2017, 7, 1001. [CrossRef]

2. Ding, Y.; Sui, C.; Li, J. An Experimental Investigation into Combustion Fitting in a Direct Injection Marine Diesel Engine. Appl. Sci. 2018, 8, 2489. [CrossRef]

3. Nguyen, D.V.; Duy, V.N. Numerical Analysis of the Forces on the Components of a Direct Diesel Engine. Appl. Sci. 2018, 8, 761. [CrossRef]

4. EL MUNDO. España pretende prohibir las matriculaciones de coches diésel, gasolina e híbridos a partir de 2040. El Mundo. 2018. Available online: https://www.elmundo.es/motor/2018/11/13/ 5beab545e2704eb15b8b45ec.html (accessed on 15 October 2019).

5. Financial Times. Dyson Presses UK Government for Earlier Petrol Car Ban. Financial Times. 2019. Available online: https://www.ft.com/content/9b078162-7195-11e9-bf5c-6eeb837566c5 (accessed on 15 October 2019).

6. Brand, C. Beyond 'Dieselgate': Implications of unaccounted and future air pollutant emissions and energy use for cars in the United Kingdom. Energy Policy 2016, 97, 1-12. [CrossRef]

7. Dey, S.; Caulfield, B.; Ghosh, B. The potential health, financial and environmental impacts of Dieselgate in Ireland. Transp. Plan. Technol. 2018, 41, 17-36. [CrossRef]

8. Normativas de Emisiones Contaminantes en Europa (Versión Completa). Available online: https://www. dieselnet.com/standards/eu/ld.php\#stds (accessed on 15 September 2019).

9. Zhang, M.; Zhong, J.; Capelli, S.; Lubrano, L. Particulate Matter Emission Suppression Strategies in a Turbocharged Gasoline Direct-Injection Engine. J. Eng. Gas Turbines Power Trans. ASME 2017, 139, 102801. [CrossRef]

10. Payri, R.; De La Morena, J.; Monsalve-Serrano, J.; Pesce, F.C. Alberto VassalloImpact of counter-bore nozzle on the combustion process and exhaust emissions for light-duty Diesel engine application. Int. J. Engine Res. 2019, 20, 46-57. [CrossRef]

11. Lapuerta, M.; Ramos, Á.; Fernández-Rodríguez, D.; González-García, I. High-pressure versus low-pressure exhaust gas recirculation in a Euro 6 Diesel engine with lean-NOx trap: Effectiveness to reduce NOx emissions. Int. J. Engine Res. 2019, 20, 155-163. [CrossRef]

12. BP Statistical Review of World Energy. June 2018. Available online: https://www.bp.com/en/global/corporate/ energy-economics/statistical-review-of-world-energy.html (accessed on 15 September 2019). 
13. European Environment Agency. 2019. Available online: http://www.europarl.europa.eu/news/es/headlines/ society/20190313STO31218/emisiones-de-co2-de-los-coches-hechos-y-cifras-infografia (accessed on 15 September 2019).

14. Dwards, R.; Hass, H.; Larivé, J.-F.; Lonza, L.; Maas, H.; Rickeard, D. Well-to-Wheels Analysis of Future Automotive Fuels and Powertrains in the European Context; Report EUR 26236 EN. JRC Technical Reports; European Commission. Publications Office of the European Union: Brussels, Belgium, 2014. [CrossRef]

15. Christoph, B.; Hans-Dieter, K.; Sinn, H.W. Kohlemotoren, Windmotoren und Dieselmotoren: Was zeigt die $\mathrm{CO}_{2}$-Bilanz? IFO Schnelld. 2019, 72, 40-54.

16. Messagie, M. Life Cycle Analysis of the Climate Impact of Electric Vehicles. Transp. Environ. 2017. Available online: https://www.transportenvironment.org/publications/electric-vehicle-life-cycle-analysis-and-rawmaterial-availability (accessed on 15 September 2019).

17. Available online: http://berkeleyearth.org/wp-content/uploads/2017/01/Europe-air-pollution.png (accessed on 15 September 2019).

18. Blaich, M. El Motor Diésel y la Conflictiva Tendencia a la Electrificación. Interempresas.net. Automoción. 2019. Available online: http:/www.interempresas.net/Sector-Automocion/Articulos/232843-El-motor-diesel-y-laconflictiva-tendencia-de-la-electrificacion.html (accessed on 15 September 2019).

19. Neaimeh, M.; Salisbury, S.D.; Hill, G.A.; Blythe, P.T.; Scoffield, D.R.; Francfort, J.E. Analysing the usage and evidencing the importance of fast chargers for the adoption of battery electric vehicles. Energy Policy 2017, 108, 474-486. [CrossRef]

20. Los Coches Eléctricos y su Autonomía Limitada. Available online: https://www.ocu.org/coches/coches/ noticias/autonomia-coches-electricos\# (accessed on 15 October 2019).

21. Autobahn Test: Tesla Model X Beats Audi e-tron \& Jaguar I-Pace; Nextmove GmbH. Available online: https:// nextmove.de/autobahn-test-tesla-model-x-beats-audi-e-tron-jaguar-i-pace/ (accessed on 15 September 2019).

22. Tang, L.; Rizzoni, G.; Cordoba-Arenas, A. Battery Life Extending Charging Strategy for Plug-in Hybrid Electric Vehicles and Battery Electric Vehicles. IFAC Pap. Online 2016, 49, 70-76. [CrossRef]

23. Blooma, I.; Colea, B.W.; Sohna, J.J.; Jonesa, S.A.; Polzina, E.G.; Battagliaa, V.S.; Henriksena, G.L.; Motlochb, C.; Richardsonb, R.; Unkelhaeuserc, T.; et al. An accelerated calendar and cycle life study of Li-ion cells. J. Power Sources 2002, 101, 238-247. [CrossRef]

24. García, F. Alarma ante la Posible Escasez de Baterías Para Vehículos Eléctricos; El Mundo: Madrid, Spain, 2019; Available online: https://www.elmundo.es/motor/2019/05/08/5cd2ea68fdddff87418b4576.html (accessed on 15 October 2019).

25. Fuentes, V. Tesla Prevé una Escasez Mundial de Minerales que son Clave Para Fabricar las Baterías de los Coches Eléctricos. Available online: https://www.motorpasion.com/tesla/tesla-preve-escasez-mundialminerales-que-clave-para-fabricar-baterias-coches-electricos (accessed on 15 October 2019).

26. Broom, D. The Dirty Secret of Electric Vehicles; Formative Content; World Economic Forum: Geneva, Switzerland, 2019; Available online: https://www.weforum.org/agenda/2019/03/the-dirty-secret-of-electric-vehicles/ (accessed on 15 September 2019).

27. Boccardo, G.; Millo, F.; Piano, A.; Arnone, L.; Manelli, S.; Fagg, S.; Gatti, P.; Herrmann, O.E.; Queck, D.; Weber, J. Experimental investigation on a 3000 bar fuel injection system for a SCR-free non-road Diesel engine. Fuel 2019, 243, 342-351. [CrossRef]

28. Puskar, M.; Kopas, M. System based on thermal control of the HCCI technology developed for reduction of the vehicle NOX emissions in order to fulfil the future standard Euro 7. Sci. Total Environ. 2018, 643, 674-680. [CrossRef]

29. Marcin, N. Selected Issues of the Indicating Measurements in a Spark Ignition Engine with an Additional Expansion Process. Appl. Sci. 2017, 7, 295.

30. Benajes, J.; Novella, R.; De Lima, D.; Tribotté, P. Analysis of combustion concepts in a newly designed two-stroke high-speed direct injection compression ignition engine. Int. J. Engine Res. 2015, 16, 52-67. [CrossRef]

31. Luján, J.M.; Bermúdez, V.; Dolz, V.; Monsalve-Serrano, J. An assessment of the real-world driving gaseous emissions from a Euro 6 light-duty Diesel vehicle using a portable emissions measurement system (PEMS). Atmos. Environ. 2018, 174, 112-121. [CrossRef]

32. Grigoratos, T.; Fontaras, G.; Giechaskiel, B.; Zacharof, N. Real world emissions performance of heavy-duty Euro VI Diesel vehicles. Atmos. Environ. 2019, 201, 348-359. [CrossRef] 
33. Green Car Congress. ADAC Testing Finds New Diesel Cars Cleaner than Required; Euro 6c and 6d-Temp Vehicles Well below the Permissible NOx Limits. Available online: https:/www.greencarcongress.com/2019/ 02/201902-22-adac.html (accessed on 15 September 2019).

34. Serrano, J.R.; Novella, R.; Gomez-Soriano, J.; Martinez-Hernándiz, P.J. Computational methodology for knocking combustion analysis in compression ignited advanced concepts. Appl. Sci. 2018, 8, 1707. [CrossRef]

35. Chiatti, G.; Chiavola, O.; Frezzolini, P.; Palmieri, F. On the link between diesel spray asymmetry and off-axis needle displacement. Appl. Sci. 2017, 7, 375. [CrossRef]

36. Sangik, H.; Juhwan, H.; Jinwook, L. A Study on the Optimal Actuation Structure Design of a Direct Needle-Driven Piezo Injector for a CRDi Engine. Appl. Sci. 2017, 7, 320.

37. Dimitriou, P.; Burke, R.; Zhang, Q.; Copeland, C.; Stoffels, H. Electric turbocharging for energy regeneration and increased efficiency at real driving conditions. Appl. Sci. 2017, 7, 350. [CrossRef]

38. Serrano, J.R.; Arnau, F.J.; Dolz, V.; Tiseira, A.; Lejeune, M.; Auffret, N. Analysis of the capabilities of a two-stage turbocharging system to fulfil the US2007 anti-pollution directive for heavy duty diesel engines. Int. J. Automot. Technol. 2008, 9, 277-288. [CrossRef]

39. Fernández-Yáñez, P.; Armas, O.; Gómez, A.; Gil, A. Developing computational fluid dynamics (CFD) models to evaluate available energy in exhaust systems of diesel light-duty vehicles. Appl. Sci. 2017, 7, 590.

40. Huang, Y.; Surawski, N.C.; Organ, B.; Zhou, J.L. Fuel consumption and emissions performance under real driving: Comparison between hybrid and conventional vehicles. Sci. Total Environ. 2019, 659, $275-282$. [CrossRef]

41. Andwari, A.M.; Pesiridis, A.; Karvountzis-Kontakiotis, A.; Esfahanian, V. Hybrid electric vehicle performance with Organic Rankine Cycle Waste Heat Recovery system. Appl. Sci. 2017, 7, 437. [CrossRef]

42. Benajes, J.; García, A.; Monsalve-Serrano, J.; Boronat, V. Dual-fuel combustion for future clean and efficient compression ignition engines. Appl. Sci. 2016, 7, 36. [CrossRef]

43. Mustafa, A.; Ahmet, I.; Çelik, M. The Impact of Diesel/LPG Dual Fuel on Performance and Emissions in a Single Cylinder Diesel Generator. Appl. Sci. 2018, 8, 825.

44. Torregrosa, A.J.; Broatch, A.; Novella, R.; Gomez-Soriano, J.; Mónico, L.F. Impact of gasoline and diesel blends on combustion noise and pollutant emissions in premixed charge compression ignition engines. Energy 2017, 137, 58-68. [CrossRef]

45. Bermúdez, V.; Serrano, J.R.; Piqueras, P.; Sanchis, E. On the impact of particulate matter distribution on pressure drop of wall-flow particulate filters. Appl. Sci. 2017, 7, 234. [CrossRef]

46. Qiao, Q.; Zhao, F.; Liu, Z.; Jiang, S.; Hao, H. Comparative Study on Life Cycle $\mathrm{CO}_{2}$ Emissions from the Production of Electric and Conventional Vehicles in China. Energy Procedia 2017, 105, 3584-3595. [CrossRef]

47. ACEA-The Automobile Industry Pocket Guide 2018-2019. Available online: https://www.acea.be/ publications/article/acea-pocket-guide (accessed on 15 September 2019).

48. Kan, H.; Chen, R.; Tong, S. Ambient air pollution, climate change, and population health in China. Environ. Int. 2012, 42, 10-19. [CrossRef]

49. Mayer, A.; Wyser, M.; Czerwinski, J. Erfahrungen mit Partikelfilter-Nachrüstungen bei Baumaschinen in der Schweiz. In Proceedings of the FAD-Konferenz, Dresden, Germany, 12-13 November 2003.

50. Has the Government Got It Wrong on 'dirty Diesel' Cars? Tests Show Some BMW, Mercedes and Vauxhall Models Produce almost ZERO Harmful NOx Emissions. Available online: https://www.thisismoney.co.uk/money/cars/article-6733271/Are-diesel-cars-really-dirty-Tests-revealmodels-produce-zero-NOx-emissions.html (accessed on 26 September 2019).

51. Serrano, J.R.; Piqueras, P.; Abbad, A.; Tabet, R.; Bender, S.; Gomez, J. Impact on Reduction of Pollutant Emissions from Passenger Cars when Replacing Euro 4 with Euro 6d Diesel Engines Considering the Altitude. Energies. 2019, 12, 1278. [CrossRef]

52. Ritchie, H.; Roser, M. $\mathrm{CO}_{2}$ and Greenhouse Gas Emissions. Available online: https://ourworldindata.org/co2and-other-greenhouse-gas-emissions (accessed on 15 September 2019).

53. Cormos, A.M.; Cormos, C.C. Techno-economic evaluations of post-combustion $\mathrm{CO}_{2}$ capture from sub- and super-critical circulated fluidized bed combustion (CFBC) power plants. Appl. Therm. Eng. 2017, 127, 106-115. [CrossRef]

54. Kramer, U. Defossilizing the Transportation Sector. Options and requirements for Germany. Fvv Prime Movers. Technologies. 2018. Forschungsvereinigung Verbrennungskraftmaschinen e.V. Lyoner Strasse 1860528 Frankfurt/ M., Germany. www.fvv-net.de/en. Available online: 
https://www.fvv-net.de/fileadmin/user_upload/medien/materialien/FVV_Future_Fuels_Study_report_ Defossilizing_the_transportation_sector_R586_final_v.3_2019-06-14_EN.pdf (accessed on 15 October 2019).

55. Hamad, E.Z.; Al-Sadat, W.I. Apparatus and Method for Oxy-Combustion or Fuels in Internal Combustion Engines. U.S. Patent 2013/0247886 A1, 26 September 2013.

56. Sun, H.; Wang, W.; Koo, K.P. The practical implementation of methanol as a clean and efficient alternative fuel for automotive vehicles. Int. J. Engine Res. 2019, 20, 350-358. [CrossRef]

57. Desantes, J.M.; Benajes, J.; Serrano, J.R.; Arnau, F.; Garcia-Cuevas, L.M.; Serra, J.M.; Catalán, D. Motor de Combustión Interna; OEPM Madrid: Madrid, Spain, 2019; 201930285.

58. Johnson, T.; Joshi, A. Review of Vehicle Engine Efficiency and Emissions. Sae Tech. Pap. 2018. [CrossRef]

59. Nieuwste Diesels Reinigen de Lucht. Available online: https://autonieuws.be/uitlaat/4756-nieuwste-dieselsreinigen-de-lucht (accessed on 15 September 2019).

60. Wissenschaftliche Gesellschaft für Kraftfahrzeug-und Motorentechnik e.V. The Future of the Combustion Engine/Assessment of the Diesel Engine Situation; WKM: Berlin, Germany, 2017.

61. Aparicio, F.; Casanova, J.; López, J.M.; Payri, F.; Tinaut, F.V.; Wolff, G. El Automóvil en la Movilidad Sostenible; Informe ASEPA; ASEPA: Madrid, Spain, 2018.

62. Troy, R.; Singh, H.B.; Majeau-Bettez, G.; Strømman, A.H. Comparative Environmental Life Cycle Assessment of Conventional and Electric Vehicles. J. Ind. Ecol. 2012, 17, 53-64. [CrossRef]

63. Diesel-PKW Dürfen Nach Erfolgreicher Hardware-Nachrüstung Weiter Einfahren. Available online: https://www.bmu.de/pressemitteilung/bundestag-beschliesst-einheitliche-regeln-fuer-umgang-mitverkehrsverboten/ (accessed on 15 October 2019).

64. Euro 6D-Temp Diesel Like Petrol. France Tries to Adapt the Anti-Pollution Stamps. Available online: https: //www.diesel-international.com/automotive/france-euro-6d-temp-diesel/ (accessed on 15 October 2019).

(C) 2019 by the authors. Licensee MDPI, Basel, Switzerland. This article is an open access article distributed under the terms and conditions of the Creative Commons Attribution (CC BY) license (http://creativecommons.org/licenses/by/4.0/). 